Clemson University

TigerPrints

7-2021

Exploring kindergarten teachers' classroom practices and beliefs in writing

Ying Guo

Cynthia Puranik

Megan Schneider Dinnesen

Anna H. Hall

Follow this and additional works at: https://tigerprints.clemson.edu/eugene_pubs

Part of the Teacher Education and Professional Development Commons 
Exploring Kindergarten Teachers' Classroom Practices and Beliefs in Writing 


\begin{abstract}
The purpose of this descriptive study was to examine how kindergarten teachers reportedly teach writing in classrooms and their beliefs about writing using survey methodology. Participants in this study included 78 kindergarten teachers in the United States. Results revealed that most kindergarten teachers used a balanced approach to writing instruction, combining instructional procedures from two common methods for teaching writing: skills instruction and process writing. The majority of kindergarten teachers devoted considerable time to writing instruction (36 minutes a day) and student writing (24 minutes a day) and used most of the instructional practices to teach writing which were included in the survey. These positive findings must be tempered by other issues involving classroom writing practices. This included concerns that teaching foundational skills were overemphasized with little attention devoted to teaching writing strategies and process; writing tasks involved writing without composing and limited extended writing; the use of technology for writing and writing instruction was absent; and motivation for writing and extending writing to the home were largely ignored. Most of participating teachers expressed positive beliefs about writing, their effectiveness to teach writing, and their capabilities as a writer.

Keywords: Writing, Kindergarten, Instructional practices, Beliefs
\end{abstract}




\section{Exploring Kindergarten Teachers' Classroom Practices and Beliefs in Writing}

The ability to write is critical to academic success throughout the school years and into early adulthood (Biancarosa \& Snow, 2004; National Commission on Writing, 2004). Children who write proficiently are more likely to be proficient readers, succeed in school, and pursue higher education (Graham, Harris, \& Hebert, 2011). However, data from the National Assessment of Educational Progress (NAEP) show that more than 54\% of eighth-graders and $52 \%$ of twelfth-graders fail to exhibit proficient writing skills (NAEP, 2011). Moreover, prevalence rates for writing disabilities in school-aged children (6.9\% to $14.7 \%)$ rival those for reading disabilities (5\% to 18\%; Katusic, Colligan, Weaver, \& Barbaresi, 2009; Shaywitz \& Shaywitz, 2005). Given the theoretical and practical importance of writing, the National Governors Association Center for Best Practices and the Council of Chief State School Officers has placed writing at the center of the school reform movement in its creation of the Common Core State Standards (CCSS, 2010; Graham, 2013). The CCSS provide consistent and appropriate benchmarks for a variety of writing skills that students should master at each grade level in kindergarten through grade 12.

Although current efforts are promising, one barrier to evaluating and implementing these writing standards is that there is little data on what writing instruction looks like in schools (Cutler \& Graham, 2008; Graham, Gillespie, \& McKeown, 2013). This lack of information makes it difficult to determine whether teachers use effective instructional practices and what needs to be done to support writing teachers. It also complicates and compromises teachers' implementation of CCSS. To this end, the purpose of this study was to provide a comprehensive

analysis of kindergarten writing instruction using survey methodology. In this study, we focused specifically on kindergarten classrooms for two major reasons. One, there is a consensus across 
researchers, policymakers, and practitioners that waiting until later grades to address literacy problems that have their origin at the early primary grades is not successful (e.g., Torgesen, 2000; Snow, Burns, \& Griffin, 1998). Given that formal writing instruction begins in kindergarten, participation in high-quality writing programs in kindergarten classrooms is one of the most viable solutions for preventing early delays in writing from progressing into serious writing disabilities that require intensive and expensive remediation. Hence, exploring kindergarten writing may hold great promise for promoting long-term impact on student writing achievement. Two, there is little data on the writing practices of kindergarten teachers. Most studies examining writing practices in elementary schools have focused on teachers in grades 1 4 (Cutler \& Graham, 2008; Graham, 2019; Graham, Harris, et al., 2008; Graham, Morphy, et al., 2008).

\section{Classroom Writing Instruction}

There is a small but growing body of research, examining the writing instruction of primary grade teachers (see Graham, 2019). Most findings come from survey and observation studies and cover four aspects of writing instruction in school: (a) approaches to writing instruction and use of commercial materials, (b) time devoted to writing instruction and writing, (c) types of writing tasks, and (d) instructional practices in writing.

In terms of approaches to writing instruction, previous surveys of teachers in grades 1-3 showed that most teachers indicated they used a traditional skills approach combined with process writing (Cutler \& Graham, 2008; Graham, Harris, Fink-Chorzempa, \& MacArthur, 2003). The traditional skills approach emphasizes the explicit and systematic teaching of foundational writing skills like handwriting, spelling, and sentence construction with little attention on the process of writing. In contrast, the process writing approach typically 
emphasizes the process of writing by engaging children in cycles of planning, translating, and revising, providing opportunities to compose meaningful texts for authentic purposes, and valuing personal responsibility for writing (including self-reflection and evaluation; Pritchard \& Honeycutt, 2006). The explicit teaching of writing skills is provided as students' learning needs naturally arise (Nagin, 2003). These finding indicate that the majority of primary grade teachers favor a more balanced approach to writing instruction. In terms of using commercial materials, Cutler and Graham (2008) found that most teachers in grades 1-3 did not use any commercial program to teach writing, handwriting, spelling, or writing process.

Several survey and observation studies have discerned how much time teachers spent teaching writing and how much time their students spent writing (Brindle, Harris, Graham, \& Hebert, 2016; Coker et al., 2016; Christenson, Thurlow, Ysseldyke, \& McVicar, 1989; Coker, Jennings, Farley-Ripple, \& MacArthur, 2018; Cutler \& Graham, 2008; Graham et al., 2003). General conclusions support that a majority of primary grade teachers do not devote enough time to teaching writing and providing opportunities for students to practice writing (Graham, 2019). For example, previous studies indicated that at the elementary school level, the typical teacher spent much less than the research recommendation of one hour per day teaching writing (Coker et al., 2016; Cutler \& Graham, 2008; Graham et al., 2003; Graham et al., 2012). With respects to how much time students spend writing, previous research demonstrated that elementary school students (grades 1-3) spent only 20-25 minutes per day writing (Coker et al., 2018; Cutler \& Graham, 2008; Graham et al., 2003). Most of the studies mentioned above have observed or surveyed writing practices in grade 1 or above. There is a dearth of information about time devoted to writing instruction and student writing in kindergarten classrooms (except Puranik, $\mathrm{Al}$ Otaiba, Sidler, \& Greulich, 2014). When Puranik and her colleagues (2014) observed 
kindergarten writing instruction; they reported seeing very little writing instruction and student writing. Specifically, on average only 6.1 minutes in the fall and 10.5 minutes in the winter were devoted to writing instruction and student writing. Although many studies have examined time devoted to writing instruction, only a few studies have examined the organizational structure of teaching writing. These studies demonstrated that primary-grade teachers most often taught writing in a whole group setting, with small group and individual instruction occurring less frequently (Coker et al., 2016; Cutler \& Graham, 2008; Graham et al., 2008).

Researchers have identified a broad range of potentially efficacious writing tasks for improving children's reading and writing skills, such as making lists, journal writing, story writing, composing personal narratives, writing a book review, responding to text in writing, and using writing as a part of inquiry (e.g., DeBaryshe \& Gorecki, 2007; Graham \& Hebert, 2010, 2011; McCarrier, Pinnell, \& Fountas, 2000). A small number of studies have examined the types of writing tasks teachers assign to their students. Findings from previous national surveys with students in grades 1-6 indicated that although students in those grades engaged in a range of writing tasks, writing was mostly limited to writing narratives (stories, personal narratives, and poems; Cutler \& Graham, 2008; Gilbert \& Graham, 2010). In an observational study of firstgrade teachers, the most common writing activities were copying text and responding to a question with a single correct answer made up of single words and sentences most of the time (Coker et al., 2018). Examined together, these findings indicate that the writing tasks assigned to students most often involve very little extended, meaningful, and useful engagement.

Given that research-supported instructional practices is a central element of school reform efforts, several studies have assessed the extent to which primary grade teachers use instructional practices to promote students' writing (Coker et al., 2016; Cutler \& Graham, 2008; 
Graham, Harris, et al., 2008; Graham, Morphy, et al., 2008). These instructional practices include teaching students foundational writing skills (e.g., handwriting, spelling, and sentence construction), teaching strategies for carrying out writing processes (e.g., planning, revision), conducting assessments to guide writing instruction, and connecting writing to reading and other content areas. Three general conclusions emerged from these survey and observational studies. First, whereas the majority of primary grade teachers used a variety of instructional practices to teach writing, they applied each strategy infrequently, often less than once a month (Graham, Harris, et al., 2008; Graham, Morphy, et al., 2008). Second, primary grade teachers overemphasized teaching foundational writing skills (e.g., handwriting, spelling, sentence construction), but allocated little attention to teaching the process of writing (e.g., planning, revising). Third, several evidence-based practices for teaching writing were rarely used in the typical elementary classroom. These included extending writing to the home and connecting writing to reading(Cutler \& Graham, 2008); motivation for writing (Wilcox, Jeffery, \& GardnerBixler, 2016), and the use of technology for writing and writing instruction (Cutler \& Graham, 2008; Coker et al., 2016).

\section{Teachers' Beliefs about Writing}

Previous research suggests that teachers' beliefs about writing impact their practices (Gilbert \& Graham, 2010; Graham, Harris, Fink-Chorzempa, \& MacArthur, 2002). Teachers who are more positive about writing, their effectiveness to teach writing, and their capabilities as a writer may be more likely to teach writing, increasing the probability that they use researchbased writing practices. Thus, it is important to examine teachers' beliefs about writing (as it was done in the present study). 
Several survey studies have examined a broader array of teachers' beliefs (e.g., effectiveness about teaching writing, attitudes toward teaching writing, and attitudes toward writing; Brindle et al., 2016; Cutler \& Graham, 2008; Gillbert \& Graham, 2010; Hsiang, Graham, \& Yang, 2020). Previous research with first to third grade teachers indicated that teachers were moderately positive about their effectiveness teaching writing and their attitudes toward teaching writing and their own writing (Cutler \& Graham, 2008; Hsiang et al., 2020). We are not aware of any studies examining kindergarten teachers' beliefs about writing.

\section{Aims of the Present Study}

The previous studies have provided insight into the nature of teaching writing, but little is currently known about writing instruction in kindergarten classrooms and teachers' beliefs related to teaching writing. Data on kindergarten teachers' approaches to teaching writing, time devoted to writing/writing instruction, types of writing tasks assigned, application of instructional practices, and beliefs about writing are needed to determine more precisely if writing reform is required at this grade level. To replicate and extend previous studies, we conducted a survey in the United States with kindergarten teachers to investigate how kindergarten teachers reportedly teach writing in classrooms and their beliefs related to writing. Teachers' beliefs focused on perceptions of effectiveness teaching writing and managing the writing classroom and attitude toward their own writing and teaching writing. The specific research questions addressed in this study were:

1. Which approach to writing instruction and commercial materials do teachers use?

2. How much time do teachers spend teaching writing and how much time do their students spend writing?

3. What type of writing tasks do teachers assign to their students? 
4. How often do teachers apply instructional practices in writing?

5. What are teachers' beliefs regarding their own writing and teaching writing?

\section{Method}

Data for the present study came from a larger project that examined writing instruction and kindergarten children's writing development. The larger study featured three sequential and non-overlapping cohorts of teachers and children in in the South and Midwest United States. Participants had to be teaching kindergarten children and agree to participate in all study activities. In addition, up to six children were randomly selected from each teacher's classroom for participation in the larger study.

\section{Participants}

Seventy-eight credentialed teachers from three cohorts of the larger study participated in the present study. These kindergarten teachers were from 41 elementary schools, ranging from one to four per school. All the participants were female (100\%); 80\% identified as White/NonHispanic, 19\% identified as African American, and 1\% identified as Asian American. On average, participating teachers were 38 years old (range: 23-63 years) with nearly 8 years ( $M=7.70$, range: $1-34)$ of experience teaching kindergarten children. The educational attainment of participating teachers included $29 \%$ with a bachelor's degree, $70 \%$ with a master's degree, and $1 \%$ with a doctoral degree. About $68 \%$ of teachers' classrooms were in suburban settings, with $32 \%$ in urban settings. An average classroom included 21 children $(S D=3.8$; range $=6$ to 26$)$.

\section{Survey Instrument}

A survey was administered to the participating kindergarten teachers. This survey has been utilized with $2941^{\text {st }}-3^{\text {rd }}$ grade teachers from a population of primary grade teachers (Cutler 
\& Graham, 2008). The survey includes four sections: (1) student information and approaches to writing instruction, (2) teachers' beliefs about writing, (3) time devoted to writing and type of writing tasks, and (4) writing practices.

The first section of the survey asked teachers to indicate the number of students who were above average, average, and below average writers in their classrooms. Teachers were also asked to report their approaches to teaching writing: traditional skills approach combined with process writing, process writing approach, traditional skills approach, or some other approach (which the teachers were asked to describe).

The second section included four statements that addressed teachers' beliefs about their overall effectiveness to manage their classroom during writing instruction and to teach writing, as well as their attitude towards their own writing and teaching writing. All items were answered using a six-point Likert-type scale ranging from strongly disagree (score $=1$ ) to strongly agree $($ score $=6)$.

The third section asked teachers to indicate how much time they devoted to teaching writing each week and how much time their students spent writing. Teachers were also asked to report what percentage of their instructional time was spent in whole group, small group, and individualized instruction. They were further asked if they used a commercial program to teach writing, handwriting, spelling, or any other aspect of writing and to describe the program if they did. A final question asked teachers to report which writing tasks students complete during the academic year. These 20 options included the following types of writing: stories, personal narratives, journal writing, poems, lists, book reports, books, comic strips, plays, alphabet book, completing worksheets, copying texts, drawing a picture and writing something, writing letter, autobiographies, writing to persuade, writing to inform, writing summaries, and writing in 
response to material read. In addition, teachers were encouraged to report any additional writing tasks that were not listed on the survey.

The fourth section asked teachers to indicate how often they applied 41 writing practices. Items assessed eight aspects of teaching writing: (1) supporting student writing, (2) teaching basic writing skills, (3) teaching writing processes, (4) instructional procedures, (5) promoting motivation, (6) assessing writing, (7) connecting writing to reading and other content area, and (8) extending writing to home. Thirty-six items used an 8-point scale ranging from never (score of 0) to several times a day (score of 7). Five items ("select their own writing topic", "complete their writing assignments at their own pace", "invented spellings", "multiple instructional goals", and "use a graphic organizer") used an 8-point scale ranging from never (score of 0) to always (score of 7).

Eleven items examined how often teachers, students, or both engaged in the specific activities to support student writing. These items focused on teacher/student conferences, peer conferences, planning, writing prompts, classmates helping each other with writing, revising, dictation, technology used for writing, invented spelling, graphic organizers, and topic choice. Coefficient alpha for supporting student writing was .68.

Six items assessed how often teachers directly taught the following basic writing skills: spelling, capitalization, grammar, punctuation, handwriting, and sentence construction. Four items asked about teaching strategies for writing processes, including organizing text, planning, revising, and modeling writing strategies. Three items focused on general instructional procedures (mini-lessons, re-teaching, and having multiple instructional goals). Coefficient alphas for teaching basic writing skills, teaching writing processes, and instructional procedures were $.80, .57$, and .51 respectively. 
Five items assessed activities that promote students' motivation: working independently at writing centers, publishing and sharing writing with peers, and teachers modeling love of writing and reading their own writing. Four items asked about the use of the following assessment practices: teacher monitoring writing processes, students monitoring writing processes, writing portfolios, and rubrics. Another three items asked how often writing was connected to reading and other content areas: writing to support reading, reading to support writing, and writing in other content areas. Finally, four items addressed the strategies used by teachers to extend writing to the home: writing homework, writing at home with parental help, parents listening to students' writing, and teacher/parent communication about writing. Coefficient alphas for promoting motivation, assessing writing, connecting writing to reading and other content area, and extending writing to home were $.68, .50, .68$, and .67 respectively.

\section{Procedure}

Only the data collected regarding teachers' classroom practices and beliefs in writing are discussed in the present study. The research team contacted local school districts to get permission to recruit teachers. Next, 10-minute information sessions were provided to kindergarten teachers explaining the study and study requirements. Once teachers consented, they completed a demographic survey adapted from the Early Childhood Longitudinal Study. This questionnaire gathered basic information about teachers (e.g., level of education) and their classrooms/schools (e.g., number of children) in the fall of the academic year (September to October). Later, these teachers completed a survey about their classroom practices and beliefs in writing in the winter of the academic year (January to February).

\section{Results}

\section{Approaches to Writing Instruction and Use of Commercial Materials}


When kindergarten teachers were asked which approaches best described their writing instruction, $80 \%$ reported that they used a traditional skills approach combined with process writing, $7.1 \%$ process writing, and $4.3 \%$ a traditional skills approach. Six teachers responded "other" approach.

Seventy-one percent of participants reported that they used a commercial program to teach writing, handwriting, spelling, or any other aspect of writing and listed 10 different programs that they used. The most common program listed (40\%) was Units of Study-Writing Workshop (Calkins, 2006). The next most common program (17\%) was Zaner-Bloser Handwriting. The remaining programs ranged from Handwriting Without Tears to ReadyGEN to $6+1$ traits. One teacher indicated that she did not know which approach she used.

\section{Time Devoted to Writing Instruction and Writing}

When time children spent writing and time spent teaching writing were summed, the mean was 293.66 minutes per week $(S D=329.08$; Range $=10-1,830)$. On average, kindergarten children in the participating teachers' classrooms received about 180 minutes of instruction in writing per week $(\mathrm{M}=181.37 ; S D=255.75 ;$ Range $=10-1,530)$ and spent about 120 minutes a week writing text that was a paragraph length or longer $(\mathrm{M}=116.76 ; S D=110.50 ;$ Range $=2.5$ 600). When examining the time spent in specific writing instruction, we found that on average, participating teachers spent 48 minutes a week teaching spelling, 49 minutes a week teaching handwriting, 26 minutes a week teaching revising strategies, 37 minutes a week teaching grammar and usage, and 25 minutes a week teaching planning strategies. In addition, we examined the organizational structure of teachers' instructional time in writing. On average, kindergarten teachers indicated that they spent $46 \%$ of their instructional time in writing with a whole group, $26 \%$ with small groups, and $21 \%$ with individual children. 


\section{Writing Tasks}

Table 1 presents information on the percentage of teachers who reported their students would complete each of 20 writing tasks during the school year. As can be seen in Table 1, the most frequent writing tasks included drawing a picture and writing towards or sentences to accompany the picture (97\%), completing worksheets (78\%), writing to inform (77\%), composing personal narratives $(73 \%)$, writing stories $(72 \%)$, and copying texts $(72 \%)$. The least frequent writing activities in the kindergarten classrooms involved making comic strips (1\%), writing plays (1\%), and writing biographies (5\%). In addition to reporting whether children in their classrooms completed the 20 writing activities listed on the survey, teachers reported any additional writing activities that children completed. Thirteen percent of participating teachers listed additional writing activities. The additional writing activities included composing opinion and informative texts, dictating sentences, working with third grade writing mentors, and Unit of Study: How-To Writing (the unit is designed to be used in writing workshop).

\section{Instructional Practices in Writing}

Teachers indicated how often they used a variety of instructional practices in writing which included supporting student writing, teaching basic writing skills, teaching writing processes, instructional procedures, promoting motivation, assessing writing, connecting writing to reading and other content areas, and extending writing to home. As described previously, most items (36 items) that assessed teachers' use of writing practices employed an 8-point scale ranging from never (score of 0) to several times a day (score of 7) and five items used an 8-point scale that ranged from never (score of 0) to always (score of 7). Frequency means, and standard deviations for these items are shown in Table 2. 
For supporting student writing, the majority of teachers reportedly conferenced with students about their writing at least once a week or more often (see Table 2). A majority of teachers reported that they used the following practices once a month or more often: planning before writing, using a writing prompt to encourage student writing, asking students to revise their writing, and having students helping classmates with writing. There was variability in how often students conferenced with peers about their writing as well as how often teachers allowed their students to dictate their compositions. These practices typically occurred somewhere between daily and monthly. The use of technology to write occurred much less frequently. Sixtyseven percent of teachers reported that they never used computers for writing. Three practices for supporting students' writing were assessed using the scale ranging from never to always. The most commonly-used practice was encouraging students to use invented spelling $(\mathrm{M}=7.76, S D$ $=0.53$ ). Eighty percent of teachers reported that they always encouraged the use of invented spelling. Students' selection of their own writing topics was less common $(\mathrm{M}=4.60, S D=2.26)$. Sixty-seven percent of teachers reported using this practice at least half of the time (12\% always allowed students to choose their own writing topics). The use of graphic organizers (e.g., story map) was least common $(\mathrm{M}=2.76, S D=2.53)$ with about one third of the participating teachers reporting using graphic organizers at least half of the time (only 5\% always applied this practice).

For teaching basic writing skills, all practices were applied by a majority of teachers once a week or more often (see Table 2). This included teaching spelling, capitalization, grammar, punctuation, handwriting, and sentence construction. For teaching writing processes, the majority of teachers reported that they modeled writing strategies once a week or more often and taught text organization skills several times a month or more often. Teachers taught planning 
strategies at the same rate. Revision strategies were taught by most teachers at least once a month, with this mostly occurring several times a month or more often.

For instructional procedures, the majority of teachers reported that they conducted mini lessons once a week or more often with $46 \%$ of teachers applying this practice at least daily (see Table 2). About $77 \%$ of teachers reported that they retaught skills and strategies once a week or more often with $28 \%$ doing this at least daily. How often teachers reported designing writing lessons with multiple goals was scored from never to always. There was considerable variability in teachers' applying this practice $(\mathrm{M}=5.22, S D=1.97)$. Over $79 \%$ of teachers reported that they provided multi-goal writing lessons at least half of the time with $16 \%$ indicating that this always occurred.

For promoting motivation, the majority of teachers indicated that they had children work independently at writing centers once a week or more often. However, the following practices were applied several times a month or more often by the majority of teachers: modeling enjoyment or love of writing, reading their own writing, and asking children to share their writing with peers. It was less common for teachers to have children publish their written work. The majority of teachers did this monthly or less and $11 \%$ of teachers reported this never occurred.

With respect to assessing writing, most teachers reported that once a week or more often, they monitored their students' writing progress and encouraged their students to monitor their own writing progress (see Table 2). Having students build writing portfolios and use rubrics to assess writing were relatively less common. A sizable portion of participating teachers reported that they never have their students build writing portfolios $(32 \%)$ or use rubrics to assess their writing $(24 \%)$. 
With respect to connecting writing to reading and other content areas, the majority of teachers reported that they used writing in other content areas and used writing to support reading at least several times a month or more often. It was less common for teachers to use reading to support writing, with $42 \%$ using this practice weekly or more often. Compared with other types of writing practices, practices related to extending writing to the home were less frequently applied by teachers. Thirty-five percent of teachers reported that they never assigned writing homework and $15 \%$ did this several times a year. Similar patterns were found for asking parents to help their child write at home (never $=23 \%$; several times a year $=20 \%$ ) and asking parents to listen to their child's writing $($ never $=27 \%$; several times a year $=28 \%$ ). Fifty-six percent of teachers reported that they communicated with parents about their child's writing progress only several times a year.

\section{Teachers' Beliefs about Effectiveness and Attitude}

Table 3 presents mean, standard deviations, and ranges for each statement on teachers' perceptions of effectiveness and attitude toward their own writing and teaching writing.

Descriptive data showed that the means of these statements ranged from 4.89 to 5.21, suggesting that kindergarten teachers' overall perceptions of effectiveness and attitude toward writing are positive. Kindergarten teachers moderately agreed that they like to teach writing and write. The majority of kindergarten teachers provided high ratings to statements concerning their attitude about their own writing (73\%) and teaching writing $(85.6 \%)$. These teachers moderately agreed that they managed their writing class effectively and they were effective in teaching writing. About $71 \%$ of teachers provided high ratings to the statement about managing their writing class effectively. For the statement about effective writing teachers, $76 \%$ of teachers provided high ratings. 


\section{Discussion}

The present study examined the teaching of writing in kindergarten classrooms. Such a study is timely because writing is now at the forefront of current efforts to improve the quality of education (Graham, 2013) and there is a lack of data about how writing is currently taught at this grade level. This investigation provides information useful for determining if the existing recommendations for reforming writing instruction are based on relevant problems in the kindergarten setting. What Works Clearinghouse Practice Guide for elementary writing recommended several effective writing practices, which include providing daily time for writing instruction, directly teaching foundational writing skills such as handwriting, spelling, and sentence construction, teaching students the strategies for the various components of writing processes, and integrating the use of technology into classroom instruction in writing (Graham et al., 2012).

\section{Teaching Writing in Kindergarten}

In the present study, almost four out of five kindergarten teachers indicated that they used traditional skills approach combined with process writing. These findings were similar to results from a national survey study with 1st-3rd-grade teachers showing that the majority of teachers applied both process and traditional skills instruction (Cutler \& Graham, 2008). The findings from the current study and the prior study further support that both the traditional skills approach and process-oriented instruction are the most common approaches to teaching writing to young children in the United States (Applebee \& Langer, 2006; Graham et al., 2003; Graham, Harris, MacArthur, \& Fink, 2002). Different from the previous survey study (Cutler \& Graham, 2008), we found that the majority of kindergarten teachers in this study used a commercial program to teach writing, handwriting, spelling, or any other aspect of writing. Given that Cutler and 
Graham conducted their study over 12 years ago, we argue that at present, teachers may have more resources (e.g., commercial writing programs or curricula) than before to support the teaching of writing.

Writing is a complex and challenging task, requiring a considerable amount of time committed to student writing and writing instruction (Graham, 2018). The average teacher in this study spent 180 minutes a week (about 36 minutes a day) on teaching writing and 120 minutes (about 24 minutes a day) in student writing practices, where children wrote text at least one paragraph length or longer. These mirror findings with teachers in grades 1- 3 obtained by Cutler and Graham (2008) and Coker et al. (2016). The kindergarten teachers in this study reportedly devoted more time to student writing and writing instruction than kindergarten teachers in the previous study of Puranik et al. (2014). Differences between our results and those found by Puranik et al. may reflect key differences in the two studies. First, the study of Puranik et al. (2014) examined the amount of writing instruction and student writing observed in 2004. In contrast, we collected data in teachers' writing practices from 2017 to 2019 and thus provide a more contemporary examination of writing instruction. The inconsistent findings across two studies indicate that more writing may be occurring in kindergarten classrooms than previously reported. This may reflect the greater attention recently placed on children's writing, as reflected in national initiatives and CCSS. Second, the study of Puranik et al. (2014) examined the amount of writing instruction and student writing only during language arts instruction. However, teachers in the present study reported their time devoted to learning opportunities in writing as well as writing opportunities that are embedded within language arts instruction, other content areas (e.g., math, science), and dramatic play. Moreover, the divergent results may be related to 
differences in the accuracy of survey methodology used in the current study and observations used in Puranik et al. (2014).

Results from this study indicate that kindergarten teachers met the What Works Clearinghouse Practice guideline to devote a minimum of 30 minutes a day to the teaching of writing for children in kindergarten. However, closer examination revealed the large variability in the amount of time spent on writing instruction and student writing. Range from 10-1,530 minutes in writing instruction showed that some teachers spent only 10 minutes per week (2 minutes a day) teaching writing. Range from 2.5 to 600 minutes in student writing demonstrated that students in some classrooms spent only 2.5 minutes per week (less than 1 minute a day) writing during the school day. These findings suggest that some kindergarten teachers may still feel overwhelmed by different demands and limited time and need additional support to teach writing. Experts suggest teachers can increase instructional time and give students more writing practice by integrating writing and content-area instruction (Graham et al., 2012).

We found that the typical kindergarten teacher in this study asked children to carry out a variety of different writing tasks. The six most common writing tasks (used by the majority of teachers) were drawing a picture and labeling it, completing worksheets, writing to inform, composing personal narratives, writing stories, and copying texts. These tasks mostly involved writing without composing (e.g., completing worksheets, copying texts) and limited extended writing. These findings were similar to those reported by Cutler and Graham (2008) and Gilbert and Graham (2010). It is important to note that different from the previous study (Cutler \& Graham, 2008) showing that writing tasks were mostly limited to narratives, an expository writing task (i.e., writing to inform) was among the most common tasks in the current study. This 
finding was positive in light of the expectations set in the CCSS for composing both narrative and expository texts.

We found that in general, most kindergarten teachers applied a variety of instructional practices, but there was considerable variability in terms of how often a practice was used. Cutler and Graham (2008) found similar findings in 1st-3rd-grade teachers. Six specific themes were evident in teaching writing to children in kindergarten classrooms. First, kindergarten teachers in this study rarely used technology (i.e., computers) as part of their writing program. Specifically, $67 \%$ of kindergarten teachers reported that they never used computers during the writing period. This finding was consistent with previous studies with teachers in grades 1-3 (Cutler \& Graham, 2008; Coker et al., 2016) and teachers in grades 4-6 (Gilbert \& Graham, 2010) that also found that computers were rarely used in teachers' writing programs. Empirical research shows the positive effects of computer use on different stages of writing development (Goldberg, Russell, \& Cook, 2003). CCSS recommends that technology should be a more integral part of writing instruction. Beginning in kindergarten, children are expected to explore and use a variety of technologies for writing. Thus, elementary schools will need to devote considerable attention to computer applications for writing, at least for kindergarten children.

Second, the participating kindergarten teachers overemphasized teaching foundational writing skills (e.g., handwriting, spelling, sentence construction), while placing comparatively little emphasis in teaching writing strategies and processes (e.g., planning, revising). This was observed in 1st-3rd grade teachers in the studies conducted by Cutler and Graham (2008) and Coker et al., (2016). Research demonstrates explicitly teaching young students how to plan and revise has positive impacts on students' writing quality (average weighted effect size for writing quality: $d=1.02,20$ studies, grades 2-6; Graham et al., 2012). Furthermore, the What Works 
Clearinghouse Practice Guide for elementary writing suggested teaching a variety of strategies for carrying out each component of the writing process (e.g., planning, drafting, evaluating, revising). Based on our results, we recommend that kindergarten teachers balance their instructional time between teaching foundational writing skills and teaching writing strategies and processes. Whereas young writers must devote considerable attention to learning how to write letters fluently, spell words correctly, and so forth before they become proficient, composing a text and learning the strategic processes involved in writing should not be ignored.

Third, kindergarten teachers in the current study rarely used practices to promote children's motivation for writing. Whereas these teachers frequently asked children to work independently in the writing center (at least weekly), other motivational activities including modeling enjoyment or love of writing, reading their own writing, asking children to share writing with peers, and have children publish their written work occurred much less frequently. There are empirically compelling cases to support the importance of motivation in writing development (Graham, Berninger, \& Fan, 2007; Graham, Kiuhara, Harris, \& Fishman, 2017). Considering the age of kindergarten children, teachers should be encouraged to implement a broad portfolio of strategies to promote children's motivation for writing which could impact their future success in writing.

Fourth, kindergarten teachers in this study frequently monitored their students' writing progress and had students self-monitor (at least weekly). These findings suggest that similar to teachers in grades 1- 3 (Cutler \& Graham, 2008), kindergarten teachers also view assessment as an integral part of their writing program. However, it is important to note that our data did not address how progress is monitored and if teachers use monitoring results to guide writing 
instruction. Thus, additional research is needed to better understand what and how kindergarten teachers assess in writing.

Fifth, kindergarten teachers connected writing to reading and other content areas at least several times a month or more often. In contrast, teaching reading to support writing occurred less frequently. Meta-analyses demonstrated that teaching reading skills had positive, significant effects on writing quality with an average effect size of .56 and this impact was maintained over time with an average effect size of .37 (preschool-grade 12; Graham et al., 2018). Given the importance of reading instruction in writing and the findings from this study, we suggest that reading and reading instruction should be part of the writing program in kindergarten classrooms. Activities including reading to support writing such as discussing letter-sound correspondence during the writing of text, analyzing the word into its constituent phonemes as children prepare to spell words, and discussing text genres (e.g., narrative structure) while generating a writing sample (Craig, 2006; Cutler \& Graham, 2008) would be beneficial.

Finally, the kindergarten teachers in the present study did not report making efforts to extend writing to the home environment. Over half of the kindergarten teachers in this study reported assigning writing homework once a month or less often. In addition, other practices designed to build strong connections between school and home were used sparingly (several times a year or less) by most kindergarten teachers. These included asking parents to help their child write at home and listen to their child's writing and communicating with parents about their child's writing progress. Increasing home-school connections to support the children's writing development might be an additional avenue for teachers to promote writing development.

\section{Teachers' Beliefs}


The majority of kindergarten teachers participating in this study moderately agreed that they were effective teachers of writing and effective in managing classroom writing activities. They also moderately agreed that they liked to teach writing and liked writing themselves. These findings are consistent with findings with 1st-3rd grade teachers from previous studies (Cutler \& Graham, 2008; Hsiang et al., 2020). The most important contribution of this study is that it examined beliefs about effectiveness and attitude toward teaching writing with kindergarten teachers. Almost all prior investigations examining teachers' writing beliefs have been conducted with teachers in grade one or above. Additional research is needed to replicate these findings and to determine the role of kindergarten teachers' beliefs about writing in shaping their writing practices.

\section{Limitations}

Several limitations of this work should be noted. First, information regarding classroom writing practices was gathered through self-report survey which could be subject to bias. Teachers' responses may be based on what they believe they should do rather than actual practice. Future research of classroom writing practices should combine use of survey data and observational approach, which may provide an unbiased estimate of the frequency with which writing practices occur within classrooms. Second, kindergarten teachers in this study were asked to report their writing practices only once across the academic year. If these teachers were queried at multiple time points, we may have found different results and arrive at a clearer picture of what writing instruction looks like within the kindergarten classrooms. Repeating surveys throughout the year could also have improved the reliability of the survey data. Third, the present study exclusively focused on teachers' beliefs about their effectiveness to teach writing and manage their writing classroom as well as their attitude toward their own writing and 
teaching writing. However, there are other types of teacher writing beliefs that shape teachers' writing instruction, including teachers' beliefs about the role of explicit instruction, correctness in students' writing, and natural learning methods (Brindle et al., 2016; Graham et al., 2002; Hsiang et al., 2020). Future study should examine a larger variety of teacher writing beliefs. Finally, this study focused solely on classroom writing practices. We did not examine the factors such as school or district policies that also influence writing instruction. Moreover, we did not investigate all aspects of classroom writing practices. For example, we did not examine kindergarten teachers' adaptions for children's experiencing difficulties with writing. Future research should apply a broader lens to study teachers' writing practices. 


\section{References}

Applebee, A. N., \& Langer, J. A. (2006). The state of writing instruction in America's schools: What existing data tell us. Albany, NY: Center on English Learning and Achievement.

Biancarosa, G., \& Snow, C. E. (2004). Reading next: A vision for action and research in middle and high school literacy. A report to the Carnegie Corporation of New York.

Washington, DC: Alliance for Excellent Education.

Brindle, M., Graham, S., Harris, K. R., \& Hebert, M. (2016). Third and fourth grade teacher's classroom practices in writing: a national survey. Reading and Writing, 29(5), 929-954. doi: 10.1007/s11145-015-9604-X

Calkins, L. (2006). Units of Study: A Guide to the Writing Workshop. Portsmouth, NH: firsthand Heinemann.

Gilbert, B. J., \& Graham, S. (2010). Teaching writing to elementary students in grades 4-6: A national survey. The Elementary School Journal, 110(4), 494-518. doi: 10.1086/651193

Graham, S., Berninger, V., \& Fan, W. (2007). The structural relationship between writing attitude and writing achievement in first and third grade students. Contemporary Educational Psychology, 32(3), 516-536. doi: https://doi.org/10.1016/j.cedpsych.2007.01.002

Graham, S., Harris, K. R., MacArthur, C., \& Fink, B. (2002). Primary grade teachers' theoretical orientations concerning writing instruction: Construct validation and a nationwide survey. Contemporary Educational Psychology, 27(2), 147-166. doi: https://doi.org/10.1006/ceps.2001.1085 
Graham, S., Kiuhara, S. A., Harris, K. R., \& Fishman, E. J. (2017). The Relationship among Strategic writing Behavior, writing motivation, and writing performance with young, developing writers. The Elementary School Journal, 118(1), 82-104. doi: 10.1086/693009

Graham, S., Liu, X., Bartlett, B., Ng, C., Harris, K. R., Aitken, A., . . Talukdar, J. (2018). Reading for Writing: A Meta-Analysis of the Impact of Reading Interventions on Writing. Review of Educational Research, 88(2), 243-284. doi:

$10.3102 / 0034654317746927$

Hsiang, T. P., Graham, S., \& Yang, Y. M. (2020). Teachers' practices and beliefs about teaching writing: a comprehensive survey of grades 1 to 3 teachers. Reading and Writing, 1-38.

Katusic, S. K., Colligan, R. C., Weaver, A. L., \& Barbaresi, W. J. (2009). The forgotten learning disability: epidemiology of written-language disorder in a population-based birth cohort (1976-1982), Rochester, Minnesota. Pediatrics, 123(5), 1306-1313.

National Commission on Writing (2004, September). Writing: A ticket to work . . or a ticket out: A survey of business leaders. Retrieved April 23, 2008, from http://www.writingcommission.org/prod_downloads/writingcom/writing-ticket-towork.pdf

National Governors Association Center for Best Practices \& Council of Chief State School Officers. (2010). Common Core State Standards for English Language Arts and Literacy in History/Social Studies, Science, and Technical Subjects: About the standards. Washington, DC: Authors. Retrieved from www.corestandards.org/about-the-standards Shaywitz, S. E., \& Shaywitz, B. A. (2005). Dyslexia (Specific Reading Disability). Biological Psychiatry, 57(11), 1301-1309. doi: 10.1016/j.biopsych.2005.01.043 
Snow, C. E., Burns, S., \& Griffin, P. (1998). Preventing reading difficulties in young children. National Research Council. Washington, DC: National Academy Press.

Torgesen, J. K. (2000). Individual differences in response to early interventions in reading: The lingering problem of treatment resisters. Learning Disabilities Research \& Practice, 15(1), 55-64. doi: 10.1207/SLDRP1501_6

Wilcox, K. C., Jeffery, J. V., \& Gardner-Bixler, A. (2016). Erratum to: Writing to the Common Core: teachers' responses to changes in standards and assessments for writing in elementary schools. Reading and Writing, 29(6), 1291-1291. doi: 10.1007/s11145-0159592-X 
Table 1.

Types of Writing Tasks Children Complete During the Academic Year

\begin{tabular}{lc}
\hline Writing task & $\begin{array}{c}\text { Percentage of teachers } \\
\text { who responded yes. }\end{array}$ \\
\hline Drawing a picture and writing something to go with it & $97 \%$ \\
Completing Worksheets & $78 \%$ \\
Writing to inform & $77 \%$ \\
Personal Narratives & $73 \%$ \\
Stories & $72 \%$ \\
Copying Text & $72 \%$ \\
Journal Writing & $69 \%$ \\
Alphabet Books & $64 \%$ \\
Lists & $60 \%$ \\
Writing letters to another person & $60 \%$ \\
Writing in response to material read & $60 \%$ \\
Writing to persuade & $53 \%$ \\
Books & $46 \%$ \\
Poems & $31 \%$ \\
Book Reports & $18 \%$ \\
Writing summaries & $15 \%$ \\
Autobiographies & $13 \%$ \\
Biographies & $5 \%$ \\
Comic strips & $1 \%$ \\
Plays & $1 \%$ \\
\hline
\end{tabular}


Table 2.

How Often Teachers Use Writing Practices

\begin{tabular}{|c|c|c|c|c|c|c|c|c|c|c|}
\hline Writing practices & Never & $\begin{array}{c}\text { Several } \\
\text { times a } \\
\text { year }\end{array}$ & Monthly & $\begin{array}{c}\text { Several } \\
\text { times a } \\
\text { month }\end{array}$ & Weekly & $\begin{array}{c}\text { Several } \\
\text { times a } \\
\text { week }\end{array}$ & Daily & $\begin{array}{c}\text { Several } \\
\text { times a } \\
\text { day }\end{array}$ & Mean & $S D$ \\
\hline \multicolumn{11}{|l|}{ Supporting student writing } \\
\hline Teacher conferences & $2 \%$ & $3 \%$ & $3 \%$ & $18 \%$ & $27 \%$ & $33 \%$ & $14 \%$ & $0 \%$ & 4.21 & 1.30 \\
\hline Planning & $8 \%$ & $10 \%$ & $7 \%$ & $22 \%$ & $21 \%$ & $13 \%$ & $19 \%$ & $0 \%$ & 3.57 & 1.84 \\
\hline Writing prompts & $4 \%$ & $17 \%$ & $7 \%$ & $20 \%$ & $25 \%$ & $12 \%$ & $13 \%$ & $2 \%$ & 3.41 & 1.77 \\
\hline Helping classmates with writing & $19 \%$ & $9 \%$ & $14 \%$ & $14 \%$ & $14 \%$ & $13 \%$ & $17 \%$ & $0 \%$ & 3.02 & 2.11 \\
\hline Revising & $18 \%$ & $17 \%$ & $9 \%$ & $21 \%$ & $18 \%$ & $7 \%$ & $10 \%$ & $0 \%$ & 2.65 & 1.93 \\
\hline Peer conferences & $27 \%$ & $14 \%$ & $8 \%$ & $23 \%$ & $14 \%$ & $8 \%$ & $5 \%$ & $1 \%$ & 2.34 & 1.95 \\
\hline Dictation & $29 \%$ & $15 \%$ & $5 \%$ & $17 \%$ & $17 \%$ & $8 \%$ & $7 \%$ & $2 \%$ & 2.36 & 2.06 \\
\hline Computers & $67 \%$ & $17 \%$ & $0 \%$ & $7 \%$ & $4 \%$ & $3 \%$ & $2 \%$ & $0 \%$ & 0.83 & 1.55 \\
\hline \multicolumn{11}{|l|}{ Teaching basic writing skills } \\
\hline Spelling skills & $5 \%$ & $1 \%$ & $0 \%$ & $4 \%$ & $13 \%$ & $24 \%$ & $36 \%$ & $17 \%$ & 5.17 & 1.69 \\
\hline Capitalization skills & $1 \%$ & $1 \%$ & $0 \%$ & $8 \%$ & $17 \%$ & $15 \%$ & $46 \%$ & $12 \%$ & 5.25 & 1.39 \\
\hline Grammar skills & $5 \%$ & $7 \%$ & $3 \%$ & $16 \%$ & $17 \%$ & $24 \%$ & $23 \%$ & $5 \%$ & 4.23 & 1.83 \\
\hline Punctuation skills & $1 \%$ & $3 \%$ & $0 \%$ & $8 \%$ & $20 \%$ & $13 \%$ & $43 \%$ & $12 \%$ & 5.14 & 1.48 \\
\hline Handwriting skills & $0 \%$ & $4 \%$ & $4 \%$ & $4 \%$ & $15 \%$ & $20 \%$ & $41 \%$ & $12 \%$ & 5.17 & 1.49 \\
\hline Sentence construction skills & $5 \%$ & $5 \%$ & $0 \%$ & $6 \%$ & $33 \%$ & $21 \%$ & $27 \%$ & $3 \%$ & 4.51 & 1.63 \\
\hline \multicolumn{11}{|l|}{ Teaching writing process } \\
\hline Modeling writing strategies & $1 \%$ & $1 \%$ & $1 \%$ & $7 \%$ & $19 \%$ & $24 \%$ & $40 \%$ & $7 \%$ & 5.05 & 1.35 \\
\hline Text organization skills & $4 \%$ & $16 \%$ & $11 \%$ & $21 \%$ & $17 \%$ & $15 \%$ & $16 \%$ & $0 \%$ & 3.43 & 1.80 \\
\hline Strategies for planning & $4 \%$ & $12 \%$ & $11 \%$ & $26 \%$ & $21 \%$ & $18 \%$ & $8 \%$ & $0 \%$ & 3.36 & 1.58 \\
\hline Strategies for revising & $11 \%$ & $12 \%$ & $20 \%$ & $24 \%$ & $17 \%$ & $8 \%$ & $8 \%$ & $0 \%$ & 2.81 & 1.69 \\
\hline \multicolumn{11}{|l|}{ Instructional procedures } \\
\hline Mini lessons & $1 \%$ & $1 \%$ & $1 \%$ & $11 \%$ & $19 \%$ & $21 \%$ & $40 \%$ & $6 \%$ & 4.95 & 1.38 \\
\hline Reteach skills & $0 \%$ & $1 \%$ & $3 \%$ & $19 \%$ & $24 \%$ & $25 \%$ & $27 \%$ & $1 \%$ & 5.22 & 1.97 \\
\hline \multicolumn{11}{|l|}{ Promoting motivation } \\
\hline Work at writing centers & $8 \%$ & $1 \%$ & $1 \%$ & $5 \%$ & $32 \%$ & $24 \%$ & $29 \%$ & $0 \%$ & 4.38 & 1.67 \\
\hline Model enjoyment or love of writing & $4 \%$ & $7 \%$ & $4 \%$ & $8 \%$ & $20 \%$ & $17 \%$ & $36 \%$ & $4 \%$ & 4.53 & 1.82 \\
\hline
\end{tabular}




\begin{tabular}{|c|c|c|c|c|c|c|c|c|c|c|}
\hline Share writing with peers & $3 \%$ & $10 \%$ & $8 \%$ & $24 \%$ & $34 \%$ & $9 \%$ & $10 \%$ & $2 \%$ & 3.52 & 1.55 \\
\hline Teacher reads own writing & $10 \%$ & $7 \%$ & $5 \%$ & $9 \%$ & $17 \%$ & $17 \%$ & $26 \%$ & $9 \%$ & 4.12 & 2.17 \\
\hline Publishing & $11 \%$ & $35 \%$ & $27 \%$ & $14 \%$ & $6 \%$ & $3 \%$ & $4 \%$ & $0 \%$ & 1.97 & 1.48 \\
\hline \multicolumn{11}{|l|}{ Assessing writing } \\
\hline Teacher monitors writing process & $0 \%$ & $5 \%$ & $5 \%$ & $21 \%$ & $25 \%$ & $17 \%$ & $23 \%$ & $4 \%$ & 4.23 & 1.49 \\
\hline Students monitor writing process & $10 \%$ & $7 \%$ & $10 \%$ & $11 \%$ & $19 \%$ & $15 \%$ & $25 \%$ & $3 \%$ & 3.79 & 2.04 \\
\hline Writing portfolios & $32 \%$ & $12 \%$ & $15 \%$ & $4 \%$ & $14 \%$ & $7 \%$ & $18 \%$ & $0 \%$ & 2.44 & 2.28 \\
\hline Student use of rubric & $24 \%$ & $24 \%$ & $22 \%$ & $16 \%$ & $5 \%$ & $3 \%$ & $6 \%$ & $0 \%$ & 1.84 & 1.65 \\
\hline \multicolumn{11}{|l|}{$\begin{array}{l}\text { Connecting writing to reading and } \\
\text { content areas }\end{array}$} \\
\hline Cross-curriculum writing & $3 \%$ & $11 \%$ & $5 \%$ & $29 \%$ & $20 \%$ & $15 \%$ & $11 \%$ & $6 \%$ & 3.73 & 1.74 \\
\hline Writing to support reading & $4 \%$ & $13 \%$ & $5 \%$ & $24 \%$ & $23 \%$ & $13 \%$ & $18 \%$ & $0 \%$ & 3.57 & 1.73 \\
\hline Reading to support writing & $12 \%$ & $14 \%$ & $14 \%$ & $22 \%$ & $19 \%$ & $11 \%$ & $12 \%$ & $0 \%$ & 2.93 & 1.84 \\
\hline \multicolumn{11}{|l|}{ Extending writing to the home } \\
\hline Writing homework & $35 \%$ & $15 \%$ & $9 \%$ & $6 \%$ & $28 \%$ & $3 \%$ & $4 \%$ & $0 \%$ & 2.03 & 1.91 \\
\hline $\begin{array}{l}\text { Students write at home with parental } \\
\text { help }\end{array}$ & $23 \%$ & $20 \%$ & $11 \%$ & $5 \%$ & $36 \%$ & $1 \%$ & $4 \%$ & $0 \%$ & 2.32 & 1.82 \\
\hline $\begin{array}{l}\text { Communicate with parents about } \\
\text { students' writing progress }\end{array}$ & $0 \%$ & $56 \%$ & $11 \%$ & $11 \%$ & $16 \%$ & $4 \%$ & $2 \%$ & $0 \%$ & 2.09 & 1.45 \\
\hline Parents listen to students writing & $27 \%$ & $28 \%$ & $17 \%$ & $7 \%$ & $15 \%$ & $1 \%$ & $5 \%$ & $0 \%$ & 1.80 & 1.72 \\
\hline
\end{tabular}


Table 3 .

Teachers' Perceptions of Effectiveness and Attitude Toward Writing

\begin{tabular}{|c|c|c|c|c|c|}
\hline & \multirow[t]{2}{*}{ Mean } & \multirow[t]{2}{*}{$S D$} & \multirow[t]{2}{*}{ Range } & \multicolumn{2}{|c|}{ Teacher response $(\%)$} \\
\hline & & & & $\begin{array}{l}\text { Low } \\
\text { rating }(0 \\
\text { or } 1)(\%)\end{array}$ & $\begin{array}{l}\text { High } \\
\text { rating ( } 4 \\
\text { or } 5)(\%)\end{array}$ \\
\hline I like to teach writing. & 5.21 & $1-5$ & 1.00 & $2.6 \%$ & $85.6 \%$ \\
\hline $\begin{array}{l}\text { I effectively manage my classroom } \\
\text { during writing instruction. }\end{array}$ & 4.89 & $2-4$ & 0.95 & $6.5 \%$ & $71 \%$ \\
\hline I like to write. & 5.03 & $1-5$ & 1.08 & $3.9 \%$ & $73.7 \%$ \\
\hline I am effective at teaching writing. & 4.93 & $2-4$ & 0.81 & $4 \%$ & $76 \%$ \\
\hline
\end{tabular}

